\title{
Desorption Behavior of Deposit Formed from Coffee Drinks on Stainless Steel Surfaces
}

\author{
Tokio TAKAhASHI, ${ }^{1}$ Tadashi NAGAI,${ }^{1}$ Takaharu SAKIYAMA ${ }^{2}$ and Kazuhiro NAKANISHI ${ }^{2}$ \\ ${ }^{1}$ Technical Development Department, Technological Development Center, Suntory Ltd., 1023-1 Yamazaki, Shimamoto-cho, Mishima- \\ gun, Osaka 618, Japan \\ ${ }^{2}$ Department of Biotechnology, Faculty of Engineering, Okayama University, 3-1-1 Tsushima-naka, Okayama 700, Japan
}

Received November 17, 1995

\begin{abstract}
The desorption behavior of fouling deposits, which had been formed on stainless steel particles from coffee drinks, was studied using various detergents. The deposit from coffee drinks was difficult to remove from stainless steel particles by $\mathrm{NaOH}$ solution which is usually effective in removing deposits consisting of organic substances. Among the detergents tested, a chlorinated alkaline cleaner was the most effective in removing the deposit formed from coffee drinks. Both in the chlorinated alkaline cleaner and $\mathrm{NaOH}$ solution, the desorption rate of the deposit followed first-order kinetics. The desorption rate constant for cleaning with the chlorinated alkaline cleaner was about 50 times that with $\mathrm{NaOH}$ solution. The desorption rate constant depended not only on the cleaning conditions but also on the conditions under which the deposit formed. In the case of a model deposit formed from a solution containing $\beta$-lactoglobulin and tannic acid, the desorption occurred in two stages. This reaction was not described by simple first order kinetics.
\end{abstract}

Keywords: cleaning, desorption, soft drink, deposit, detergent, $\beta$-lactoglobulin, tannin, stainless steel

Recently in beverage industries, many kinds of beverages are produced in the same process equipment. Thus, cleaning of the equipment is carried out regularly to remove fouling deposits and to ensure hygienic conditions. To maintain quality assurance, a cleaning in place (CIP) is adopted and conducted at least once a day. Therefore, the costs of cleaning agents, water and energy, as well as loss of production time due to cleaning, are significant. Furthermore, a large amount of waste water causes environmental problems. Elucidation of cleaning mechanisms and subsequent establishment of efficient cleaning protocols are important for the minimization of both the cost and the burden of environmental pollution.

The cleaning mechanism and kinetics are influenced by the kinds and properties of deposits to be removed (Jeurnink \& Brinkman, 1994). Different kinds of food processed and various conditions produce deposits of different compositions (Lalande et al., 1984; Foster et al., 1989). To optimize the cleaning operation in the beverage industries, it is necessary to understand the desorption behavior of deposits formed from the actual products of concern.

In our preceding paper (Takahashi et al., 1996), formation of fouling deposits from soft drinks on stainless steel particles was studied under various conditions using a laboratory-scale apparatus. Among the soft drinks tested, coffee drinks containing milk protein gave the highest amount of deposit. For deposits from milk and milk-based products, a number of studies concerning the effects of temperature (Schlüssler, 1970; Graßhoff, 1983), detergents (Jeurnink \& Brinkman, 1994; Daufin et al., 1991, 1992), detergent concentration (Jennings, 1959), and mechanical force (Jennings et al., 1957) on the cleaning efficiency have been reported. However, no study of the desorption behavior of deposits formed from coffee drinks has been reported so far.

In this study, the desorption behavior of deposits formed from coffee drinks was studied using various detergents such as sodium hydroxide solution, sequestering alkaline cleaner, chlorinated alkaline cleaner and acidic cleaner. Most of these are generally used for manufacturing processes in the dairy plant. A proteolytic enzyme solution was also tested as a detergent, because its cleaning efficiency for proteineous deposits was high as reported in our previous paper (Nagata et al., 1995).

\section{Materials and Methods}

Stainless steel particles Stainless steel particles of SUS316L (about $180 \mu \mathrm{m}$ in average diameter) were obtained from Fukuda Metal Foil \& Powder Co., Ltd. (Kyoto). They were thoroughly washed using the same method as described previously (Takahashi et al., 1996) and dried at $105^{\circ} \mathrm{C}$.

Coffee drink samples and model solutions To prepare fouled stainless steel particles, three coffee drinks (coffee drinks A, B and C) were used. For comparison, oolong tea was also used to prepare fouled stainless steel particles. These samples were the same as commercially available products, except that the samples were not pasteurized or sterilized. The coffee drinks were made from coffee extract, sugar, pasteurized milk and dried milk powder. The major compositions of these samples were shown in the preceding paper (Takahashi et al., 1996).

$\beta$-Lactoglobulin from bovine milk (3 times crystallized; Sigma Chemical Co., St. Louis, USA) and reagent grade tannic acid (Nacalai Tesque, Inc., Kyoto) were used as model substances contained in coffee drinks. $\beta$-Lactoglobulin was 
dissolved in $35 \mathrm{~mm}$ phosphate buffer, $\mathrm{pH} 6.85$, containing 100 $\mathrm{mM} \mathrm{NaCl}$ at a concentration of $0.5 \%(\mathrm{w} / \mathrm{v})$ with or without $0.15 \%(\mathrm{w} / \mathrm{v})$ tannic acid.

Detergents Reagent grade sodium hydroxide (Nacalai Tesque, Inc., Kyoto), chlorinated alkaline cleaner (ECLIN41sp; Ricoh Kyosan, Inc., Tokyo), and sequestering alkaline cleaner (AC-25; ECOLAB K.K., Tokyo) were used as alkaline detergents. The latter two are commercially available cleaners and practically used in food industries. The desorption behavior was compared using $0.1 \mathrm{~N}$ sodium hydroxide, $0.67 \%(\mathrm{w} / \mathrm{v})$ chlorinated alkaline cleaner solution, and $1.32 \%(\mathrm{w} / \mathrm{v})$ sequestering alkaline cleaner solution, all of which show the same alkalinity (normality). Hypochloric acid is generated by $0.67 \%$ chlorinated alkaline cleaner at the concentration of $360 \mathrm{ppm}$. A commercially available acidic cleaner (Apex NR; Daiya Chemical Co., Ltd., Osaka) was also used. The acidity (normality) of a $1.0 \%$ solution of the acidic detergent corresponded to $0.126 \mathrm{~N}$ nitric acid. A proteolytic enzyme preparation, Protin AC10, containing $15 \%$ protein, was obtained from Daiwa Kasei K.K. (Osaka) and used without further purification. This enzyme preparation was dissolved in $20 \mathrm{~mm}$ borate buffer, $\mathrm{pH} 9$, at a protein concentration of $17 \mathrm{ppm}$ or $100 \mathrm{ppm}$. Protin AC 10 was stable up to $50^{\circ} \mathrm{C}$, and the optimum $\mathrm{pH}$ of its proteolytic activity was between 9 and 10 (Nagata et al., 1995).

Preparation of fouled stainless steel particles Fouled stainless steel particles were prepared by the same procedure as in the adsorption experiments described in our previous paper (Takahashi et al., 1996). After the adsorption, the stainless steel particles were washed repeatedly with reagent grade pure water until the total nitrogen concentration in the waste water was less than $100 \mathrm{ppb}$ for the coffee drinks or the total organic carbon concentration was less than $200 \mathrm{ppb}$ for oolong tea. The fouled particles thus obtained were used for the following desorption experiments. A portion of the fouled particles was dried at $105^{\circ} \mathrm{C}$, and the total amounts of nitrogen and carbon deposited on the particles was measured by the Pragl-Dumas method (Miki, 1990) with a CHN Corder MT-5 (Yanaco Analytical Instrument Co., Kyoto).

The solutions of $\beta$-lactoglobulin with and without tannic acid were also used to prepare fouled stainless steel particles. The procedure was the same as described in our previous paper (Takahashi et al., 1996).

Desorption experiment One to three grams of the fouled stainless steel particles were placed into $20 \mathrm{ml}$ of a preheated detergent solution in a $100 \mathrm{ml}$ eggplant-type flask. This suspension was then incubated at a constant temperature with stirring (about $800 \mathrm{rpm}$ ). At appropriate intervals, $0.5 \mathrm{ml}$ of the bulk solution was withdrawn from the flask, and its nitrogen content was measured using the total nitrogen analyzer TN-05 (Mitsubishi Chemical Co., Tokyo) to evaluate the amount of nitrogen removed from the fouled particles. For the particles which had been fouled with oolong tea, the organic carbon content of the bulk solution was measured using the total organic carbon analyzer TOC-5000 (Shimadzu Co., Kyoto), because the deposit formed on those particles contained carbon but no nitrogen (Takahashi et al., 1996).

\section{Results}

Figure 1 shows the desorption behavior of the deposit formed from coffee drink $A$ with various alkaline detergents $($ alkalinity $=0.1 \mathrm{~N})$ and acidic detergent (acidity $=0.126 \mathrm{~N}$ ) at $70^{\circ} \mathrm{C}$. The deposit had been formed on the stainless steel particles after $18 \mathrm{~h}$ treatment with coffee drink $\mathrm{A}$ at $75^{\circ} \mathrm{C}$. The deposit was not removed by the acidic detergent at all, although it was removed slightly by $0.1 \mathrm{~N} \mathrm{NaOH}$ solution or sequestering alkaline cleaner. The chlorinated alkaline cleaner was the most efficient in removing the deposit from the stainless steel particles.

Figure 2 shows the desorption behavior of the same deposit as in Fig. 1 with various alkaline detergents and proteolytic enzyme solution at $50^{\circ} \mathrm{C}$. Among the detergents tested, $\mathrm{NaOH}$ solution showed the worst result. Even on increasing the $\mathrm{NaOH}$ concentration from 0.1 to $1 \mathrm{~N}$, there was only a slight improvement in the desorbed amount. Using the crude enzyme solution containing only $100 \mathrm{ppm}$ protein at $50^{\circ} \mathrm{C}$, the desorbed amount was much increased in comparison to 1 $\mathrm{N} \mathrm{NaOH}$ solution. However, the chlorinated alkaline cleaner (alkalinity $=0.1 \mathrm{~N}$ ) was more effective in removing the deposit formed from coffee drink $\mathrm{A}$ than the proteolytic enzyme solution.

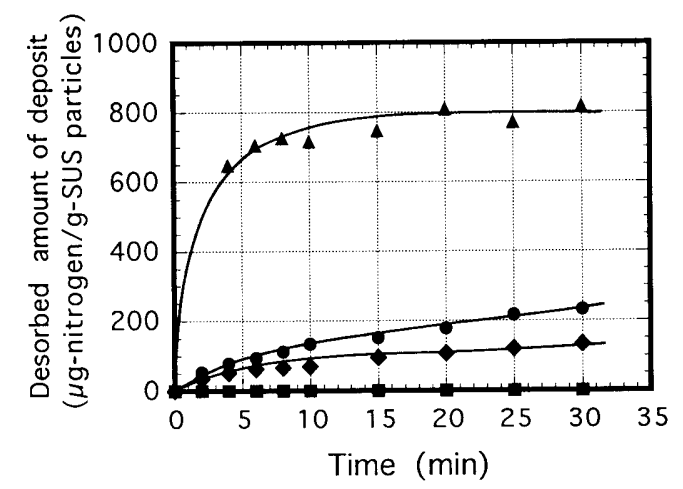

Fig. 1. Desorption behavior of the deposit formed from coffee drink A with various detergents at $75^{\circ} \mathrm{C}$. Detergents: $\bullet 0.1 \mathrm{~N} \mathrm{NaOH}, \bullet 1.32 \%$ sequestering alkaline cleaner $($ alkalinity $=0.1 \mathrm{~N}$ ), $\Delta \quad 0.67 \%$ chlorinated alkaline cleaner $($ alkalinity $=0.1 \mathrm{~N}), \mathbf{\square} 1 \%$ acidic cleaner $($ acidity $=0.126 \mathrm{~N})$.

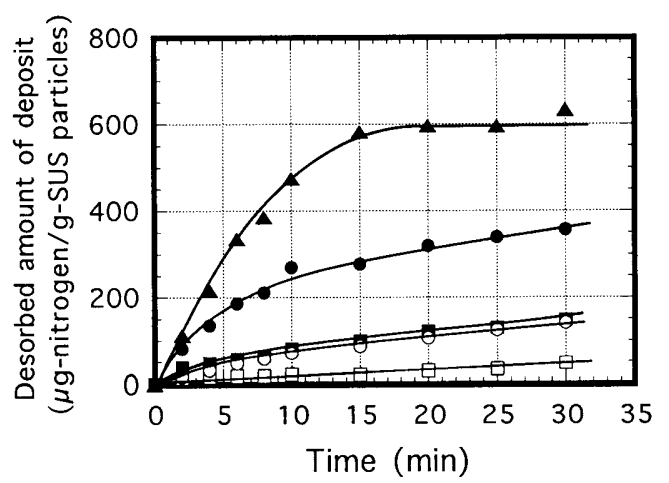

Fig. 2. Comparison of desorption behavior of the deposit formed from coffee drink A with alkaline detergents at $50^{\circ} \mathrm{C}$ and with protease solution of $\mathrm{pH} 9$ at $50^{\circ} \mathrm{C}$. Detergents: $\square 0.1 \mathrm{~N} \mathrm{NaOH}, \square 1 \mathrm{~N} \mathrm{NaOH}, \bigcirc$ proteolytic enzyme (17 ppm), proteolytic enzyme $(100 \mathrm{ppm}), \boldsymbol{\Delta} 0.67 \%$ chlorinated alkaline cleaner $($ alkalinity $=0.1 \mathrm{~N})$. 


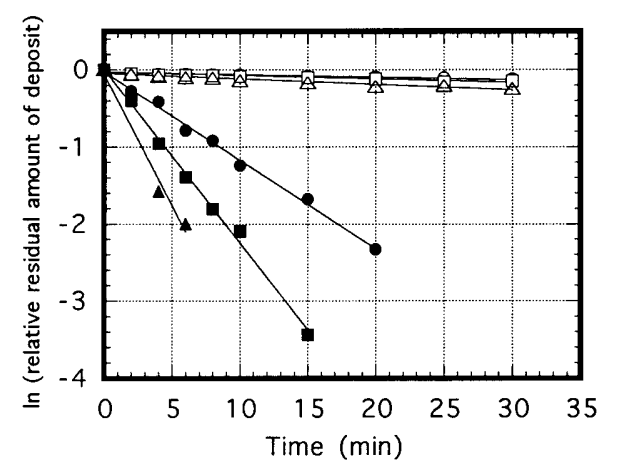

Fig. 3. Effect of temperature on the courses of desorption of the deposit formed from coffee drink A. Temperature: $\bigcirc, 50^{\circ} \mathrm{C}, \square, \square 60^{\circ} \mathrm{C}, \triangle, \Delta 70^{\circ} \mathrm{C}$ Detergent: $\bigcirc, \square, \triangle 0.1 \mathrm{~N} \mathrm{NaOH}, \bullet, \mathbf{\square}, \Delta 0.67 \%$ chlorinated alkaline cleaner $($ alkalinity $=0.1 \mathrm{~N})$.

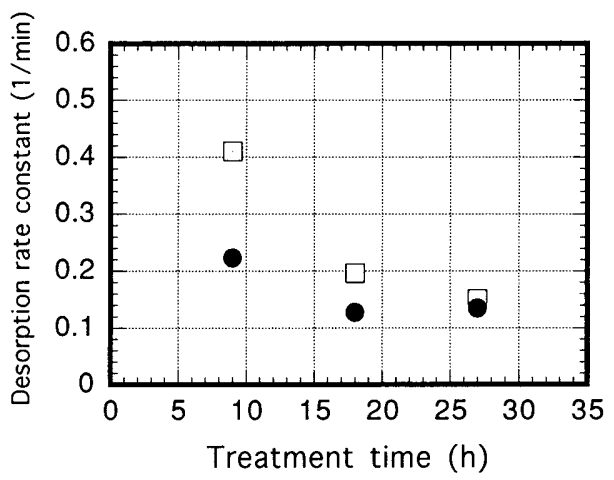

Fig. 5. Effect of fouling conditions on the courses of desorption of the deposit formed from coffee drink A. Fouling temperature: $\square 60^{\circ} \mathrm{C},-75^{\circ} \mathrm{C}$. The desorption experiments were carried out with $0.67 \%$ chlorinated alkaline cleaner at $50^{\circ} \mathrm{C}$.

Figure 3 shows the courses of the change in relative residual amount of deposit from coffee drink $A$ when $0.1 \mathrm{~N} \mathrm{NaOH}$ solution or chlorinated alkaline cleaner (alkalinity $=0.1 \mathrm{~N}$ ) was used as a detergent in a temperature range from 50 to $70^{\circ} \mathrm{C}$. The deposit had been formed after $18 \mathrm{~h}$ treatment with coffee drink $\mathrm{A}$ at $75^{\circ} \mathrm{C}$. The relative residual amount of deposit was calculated by $1-\left(S_{x} / S_{0}\right)$, where $S_{0}$ is the initial amount of deposit on the stainless steel particles and $S_{x}$ is the amount of deposit remaining on the stainless steel particles at any time. As shown in Fig. 3, a linear relationship between time and the logarithms of the relative residual amount of deposit was obtained for each condition, indicating that the residual amount of deposit decreased according to first-order kinetics. From the slope of each straight line shown in Fig. 3, the desorption rate constant (first-order rate constant) was calculated for various temperatures. Figure 4 shows the Arrhenius plot of the desorption rate constant. The desorption rate constant obtained with chlorinated alkaline cleaner was about 50 times that with $\mathrm{NaOH}$ solution. The desorption rate constants both with $\mathrm{NaOH}$ solution and chlorinated alkaline cleaner increased with increasing temperature. The activation energies for $0.1 \mathrm{~N} \mathrm{NaOH}$ solution and chlorinated alkaline cleaner (alkalinity $=0.1 \mathrm{~N}$ ) were estimated to be 40

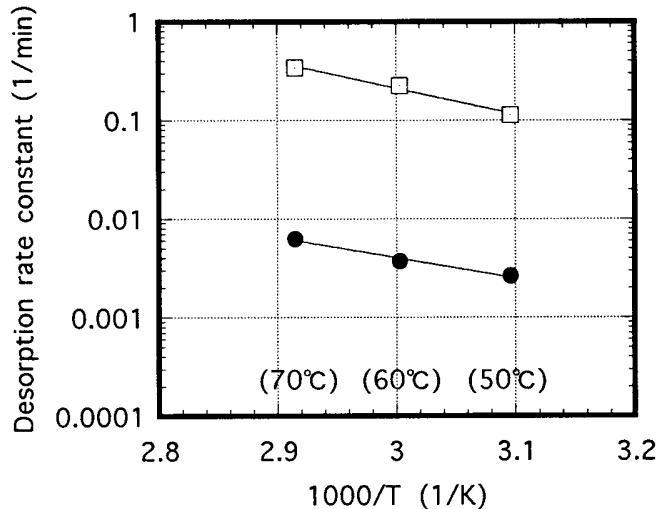

Fig. 4. Arrhenius plot of the desorption rate constant. Detergents: $0.1 \mathrm{~N}$ $\mathrm{NaOH}, \square 0.67 \%$ chlorinated alkaline cleaner (alkalinity $=0.1 \mathrm{~N}$ ).

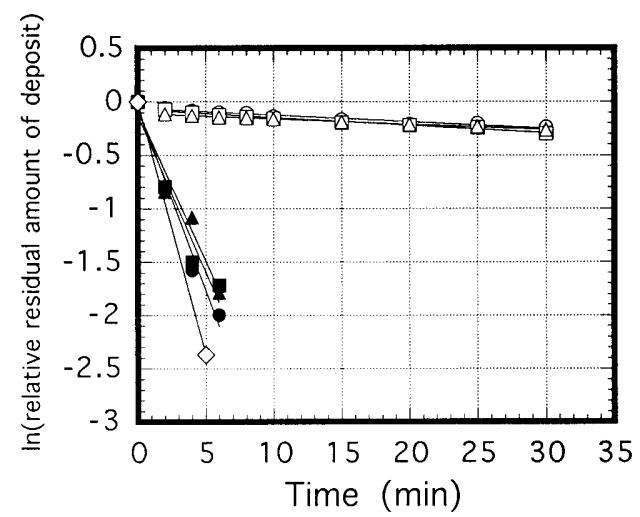

Fig. 6. Courses of desorption of deposits formed from several soft drinks at $70^{\circ} \mathrm{C}$. Deposits: $\bigcirc$, deposit formed after $18 \mathrm{~h}$ treatment with coffee drink $\mathrm{A}$ at $75^{\circ} \mathrm{C}, \square, \square$ deposit formed through $18 \mathrm{~h}$ treatment with coffee drink B at $75^{\circ} \mathrm{C}, \triangle, \Delta$ deposit formed after $18 \mathrm{~h}$ treatment with coffee drink $\mathrm{C}$ at $75^{\circ} \mathrm{C}, \diamond$ deposit formed after $18 \mathrm{~h}$ treatment with oolong tea at $95^{\circ} \mathrm{C}$. Detergents: $O, \square$, $\triangle, \diamond 0.1 \mathrm{~N} \mathrm{NaOH}, \bullet, \mathbf{a}, \Delta 0.67 \%$ chlorinated alkaline cleaner (alkalinity= $0.1 \mathrm{~N})$.

\section{$\mathrm{kJ} / \mathrm{mol}$ and $51 \mathrm{~kJ} / \mathrm{mol}$, respectively.}

Figure 5 shows the effects of fouling time and fouling temperature $\left(60^{\circ} \mathrm{C}\right.$ and $\left.75^{\circ} \mathrm{C}\right)$ on the desorption rate constant for the deposit from coffee drink A with $0.67 \%(\mathrm{w} / \mathrm{v})$ chlorinated alkaline cleaner at $50^{\circ} \mathrm{C}$. The desorption rate constant of deposit decreased with increasing fouling temperature and with an elongation of fouling time (treatment time). When the fouling time was longer than $20 \mathrm{~h}$, the difference between the desorption rate constants obtained for the two fouling temperatures became small.

The desorption behavior of the deposits formed from several drink samples (coffee drinks A, B and C, and oolong tea) was compared in Fig. 6. As a detergent, $0.1 \mathrm{~N} \mathrm{NaOH}$ or chlorinated alkaline cleaner (alkalinity $=0.1 \mathrm{~N}$ ) was used at $70^{\circ} \mathrm{C}$. The fouling temperature for the three coffee drinks were $75^{\circ} \mathrm{C}$, and that for oolong tea was $95^{\circ} \mathrm{C}$. No appreciable difference in the desorption rate constants among the deposits formed from three coffee drinks was observed either with 0.1 $\mathrm{N} \mathrm{NaOH}$ solution or the chlorinated alkaline cleaner. The desorption rate constant for the deposit formed from oolong tea with $0.1 \mathrm{~N} \mathrm{NaOH}$ solution was higher than that for the 


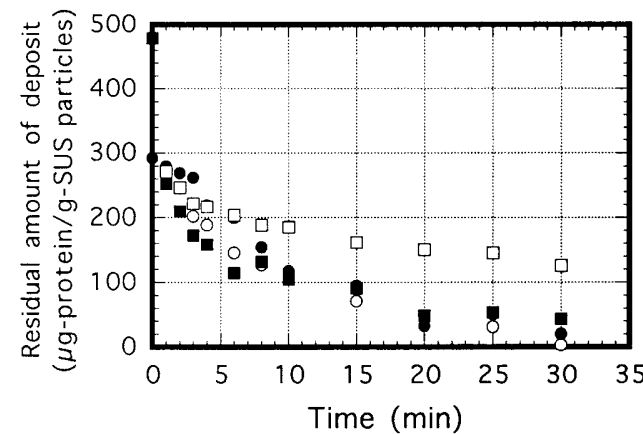

Fig. 7. Courses of desorption of the deposit formed from model solutions with $0.02 \mathrm{~N} \mathrm{NaOH}$ solution and $0.12 \%$ chlorinated alkaline cleaner at $50^{\circ} \mathrm{C}$. Deposits: $\bigcirc, \propto$ deposit formed from a solution of $\beta$-lactoglobulin, $\square, \square$ deposit formed from a mixture of $\beta$-lactoglobulin and tannic acid. Detergents: $O, \square$ $0.02 \mathrm{~N} \mathrm{NaOH}, \bullet 0.12 \%$ chlorinated alkaline cleaner (alkalinity $=0.02 \mathrm{~N}$ ).

deposits formed from coffee drinks with the chlorinated alkaline cleaner.

Figure 7 shows the results for the deposits formed after 12 $\mathrm{h}$ treatment with $0.5 \%(\mathrm{w} / \mathrm{v}) \beta$-lactoglobulin solution and with $0.5 \%(\mathrm{w} / \mathrm{v}) \beta$-lactoglobulin solution containing $0.15 \%$ $(\mathrm{w} / \mathrm{v})$ tannic acid at $75^{\circ} \mathrm{C}$. There was almost no difference in the desorption behavior of the two alkaline detergents in the case of the deposit formed from the $\beta$-lactoglobulin solution containing no tannic acid. On the other hand, the chlorinated alkaline cleaner was more efficient than $0.02 \mathrm{~N} \mathrm{NaOH}$ solution in removing the deposit formed from the $\beta$-lactoglobulin solution containing tannic acid. The desorption behavior of the deposit formed from a mixture of $\beta$-lactoglobulin and tannic acid with both detergents obeyed second order kinetics. At the end of the desorption, most of deposit was removed from the stainless steel particles, except for the deposit formed from a mixture of $\beta$-lactoglobulin and tannic acid with $0.02 \mathrm{~N} \mathrm{NaOH}$ solution.

\section{Discussion}

Alkaline cleaner is generally effective in removing deposits consisting of organic substances. For example, the deposit formed from oolong tea was easily removed by a $\mathrm{NaOH}$ solution as shown in Fig. 6. For the deposits formed from coffee drinks, however, the desorption rate with $\mathrm{NaOH}$ solutions was very low. The desorption rate was not much improved when the $\mathrm{NaOH}$ concentration was increased from 0.1 to $1 \mathrm{~N}$. Thus, the choice of detergent which is appropriate for the deposit of concern is important for reducing the time required for cleaning. A higher cleaning efficiency was obtained with the proteolytic enzyme solution than with $\mathrm{NaOH}$ solution. The desorption rate constant with the proteolytic enzyme cleaner would be improved by increasing the enzyme concentration. However, for the use of enzymes as a detergent, the cost of the enzymes and the possibility of the enzymes remaining on the surface after cleaning should be considered. Thus, at present, chlorinated alkaline cleaner seems to be most appropriate as a cleaner for the deposit from coffee drinks. The chlorinated alkaline cleaner was more effective on the complex deposit of $\beta$-lactoglobulin and tannic acid which is the model for the coffee deposit as mentioned before. Hypochloric acid which is generated by that detergent would decompose the complex deposit of $\beta$-lactoglobulin and tannic acid, and hence the coffee deposit. The rapid desorption of the model deposit only in the early stage followed by first order desorption suggests that different properties exist in the deposit.

The desorption rate constant of the deposit formed from coffee drink A varied with fouling conditions such as the fouling temperature and the fouling time. The desorption rate constant for the deposit formed at $60^{\circ} \mathrm{C}$ was higher than that formed at $75^{\circ} \mathrm{C}$ when the fouling time was within $20 \mathrm{~h}$. Thus, lowering of the heating temperature during thermal processing would shorten the time for cleaning. When the fouling time was longer than $20 \mathrm{~h}$, the desorption rate constant for the deposit formed at $60^{\circ} \mathrm{C}$ was almost the same as that formed at $75^{\circ} \mathrm{C}$. These findings suggest that the property of the deposit from the coffee drink changes with the fouling time, which implies the importance of the cleaning cycle.

\section{References}

Daufin, G., Merin, U., Labbe, J.P., Quemerais, A. and Kerherve, F.L. (1991). Cleaning of inorganic membranes after whey and milk ultrafiltration. Biotech. Bioeng., 38, 82-89.

Daufin, G., Merin, U., Kerherve, F.L., Labbe, J.P., Quemerais, A. and Bousser, C. (1992). Efficiency of cleaning agents for an inorganic membrane after milk ultrafiltration. J. Dairy Res., 59, 29-38.

Foster, C.L., Britten, M. and Green, M.L. (1989). A model heatexchanger apparatus for the investigation of fouling of stainless steel surfaces by milk. I. Deposit formation at $100^{\circ}$ C. J. Dairy Res., 56, 201-209.

Graßhoff, A. (1983). Model tests for removing firmly encrusted milk deposits from heating plates using the CIP system. Kiel. Milchwirtsch. Forschungsber., 35, 493-519.

Jennings, W.G. (1959). Circulation cleaning. III. The kinetics of a simple detergent system. J. Dairy Sci., 42, 1763-1771.

Jennings, W.G., Mckillop, A.A. and Luick, J.R. (1957). Circulation cleaning. J. Dairy Sci, 40, 1471-1479.

Jeurnink, T.J.M. and Brinkman, D.W. (1994). The cleaning of heat exchangers and evaporators after processing milk or whey. Int. Dairy J., 4, 347-368.

Lalande, M., Tissier, J.P. and Corrieu, G. (1984). Fouling of a plate heat exchanger used in ultra-high-temperature sterilization of milk. J. Dairy Res., 51, 557-568.

Lalande, M., Tissier, J.P. and Corrieu, G. (1985). Fouling of heat transfer surfaces related to $\beta$-lactoglobulin denaturation during heat procesing of milk. Biotech. Progress, 1, 131-139.

Miki, T. (1990). State-of-the-art in organic elemental micro and ultramicro analysis. Fresenius J. Anal. Chem., 337, 817-823.

Nagata, A., Sakiyama, T., Itoh, H., Toyomasu, T., Enomoto, E., Nagai, T., Saeki, T. and Nakanishi, K. (1995). Comparative study on caustic and enzymatic cleanings of stainless steel surface fouled with $\beta$-lactoglobulin. Biosci. Biotech. Biochem., 59, 2277-2281.

Schlüssler, H.J. (1970). Cleaning of surfaces in food industries. Milchwissenschaft, 25, 133-145.

Takahashi, T., Nagai, T., Sakiyama, T. and Nakanishi, K. (1996). Formation of fouling deposit from several soft drinks on stainless steel surface. Food Sci. Technol. Int., 2, 116-119. 